spring competes for niches along the Rhine River in the Netherlands. Tree Genet Genom 4: 663-675.

TAutz, D., M. TRick and G. A. Dover (1986): Cryptic simplicity in DNA is a major source of genetic variation. Nature 322: 652-656.

Tuskan, G. A., L. E. Gunter, Z. K. Yang, T. M. Yin, M. M. SEwELL and S. P. DiFAzIO (2004): Characterization of Microsatellites Revealed by Genomic Sequencing of Populus trichocarpa. Can J For Res 34: 85-93.

Tuskan, G. A., S. DiFazio, S. Jansson, J. Bohlmann et al (2006): The genome of black cottonwood, Populus trichocarpa (Torr. \& Gray). Science 313: 1596-1604.

VAN DER Schoot, J., M. Pospísková, B. Vosman and M. J. M. SMULDERS (2000): Development and characterization of microsatellite markers in black poplar (Populus nigra L.). Theor Appl Genet 101: 317-322.

Vande Walle, I., N. van Camp, L. van de Casteele, K. Verheyen and R. Lemeur (2007): Short-rotation forestry of birch, maple, poplar and willow in Flanders (Belgium) II. Energy production and $\mathrm{CO}_{2}$ emission reduction potential. Biomass \& Bioenergy 31: 276-283.
Vanden Broeck, A., M. Villar, E. Van Bockstaele and J. VAN SLYCKEN (2005): Natural hybridization between cultivated poplars and their wild relatives: evidence and consequences for native poplar populations. Ann For Sci 62: 601-613.

XING, C., F. R. Schumacher, G. XING, Q. Lu, T. WANG and R. C. Elston (2005): Comparison of microsatellites, single-nucleotide polymorphisms (SNPs) and composite markers derived from SNPs in linkage analysis. BMC Genetics 6 (suppl. 1): S29.

ZHANG, D. Q. and Z. Y. ZHANG (2005): Single nucleotide polymorphisms (SNPs) discovery and linkage disequilibrium (LD) in forest tress. For Stud China 7: 1-14.

Ziegenhagen, B., S. Gneuss, G. Rathmacher, I. Leyer, R. Bialozyt, B. Heinze and S. Liepelt (2008): A fast and simple genetic survey reveals the spread of poplar hybrids at a natural Elbe river site. Conserv Genet 9: 373-379.

\title{
A DNA Method to Verify the Integrity of Timber Supply Chains; Confirming the Legal Sourcing of Merbau Timber From Logging Concession to Sawmill
}

\author{
By A. J. LowE ${ }^{1), 2), 3), *)}$, K.-N. WonG ${ }^{4)}$, Y.-S. Tiong ${ }^{4)}$, S. IYerH ${ }^{1)}$ and F.-T. CHEW ${ }^{4)}$
}

(Received $28^{\text {th }}$ September 2010)

\begin{abstract}
Several methods are employed by the timber industry to try to restrict the flow of products from illegal or unsustainable sources into timber supply chains. The most commonly applied are systems of log marking and associated documentation that accompany the logs. However this system is open to falsification, particularly between the logging concession and the timber mill, where the majority of illegally logged timber enters the supply chain. This paper describes the development of a

1) Double Helix Tracking Technologies Pte Ltd, 96B Club Street, 069458, Singapore.

2) Australian Centre for Evolutionary Biology and Biodiversity, and School of Earth and Environmental Sciences, University of Adelaide, North Terrace, Adelaide, SA5005, Australia.

3) State Herbarium of South Australia, Science Resource Centre, Department of Environment and Natural Resources, North Terrace, Adelaide, SA5005, Australia.

$\left.{ }^{4}\right)$ Department of Biological Sciences, National University of Singapore, Science Drive 4, 117543, Singapore.

*) Author for correspondence: ANDREw J. LOWE.

Australian Centre for Evolutionary Biology and Biodiversity, and School of Earth and Environmental Sciences, University of Adelaide, North Terrace, Adelaide, SA5005, Australia. E-Mail: andrew.lowe@adelaide.edu.au
\end{abstract}

methodology to track a unique genetic fingerprint for single logs of merbau, Intsia palembanica (Leguminosae), a high-value Indonesian timber species, from logging concession to the mill, where the DNA profile of individual $\operatorname{logs}$ is difficult or impossible to falsify. We find that whilst the ability to extract DNA and amplify a PCR product from logs decreases slightly between forest concession $(59.2 \%)$ and mill $(41.9 \%)$ samples, that overall enough samples worked across the 14 microsatellite markers to provide an exact genotype match between forest and sawmill samples for 27 out of 32 logs. Furthermore for these 27 samples, the probability that an illegal log with an exact genotype match to forest samples had been substituted was very low (less than $10^{-5}$ ) for 18 samples, was low (between $10^{-2}$ and $10^{-4}$ ) for 7 samples and was moderate $\left(10^{-1}\right)$ for 2 samples. Improvements to DNA extraction and amplification success are recommended to improve this protocol, and there was a negative correlation between locus size and amplification success but a positive correlation with allele number. However, overall we propose that this methodology is now suitable for broad-scale industry application to track legally harvested timber and check for illegal substitutions along supply chains.

Key words: genetic fingerprinting, illegal logging, merbau, microsatellites, timber certification. 


\section{Introduction}

Illegal logging continues to be one of the major causes of deforestation and forest degradation, and apart from advancements in establishing protected areas and establishing sustainable certified forestry, forest loss proceeds at great speed (DEGEN and FladunG, 2008). Between 14 and 16 million hectares of forest are lost each year, most of which is in tropical regions. Beyond forest loss and resulting extinction of species, the impact that deforestation has on global warming has come to public attention, where between 20 and $25 \%$ of global $\mathrm{CO}_{2}$ emissions result from deforestation (ZAHNEN, 2008). For example in Indonesia, one of the world's largest $\mathrm{CO}_{2}$ emitters behind the USA and China, more than $80 \%$ of $\mathrm{CO}_{2}$ emissions result from deforestation. Several causes of deforestation are often combined or dependent on each other, including: use of wood, both legal and illegal; land use conversion, e.g. expansion of agriculture, livestock farming, bio-fuel and paper industry; settlements/ infrastructure; and, exploitation of mineral resources (ZAHNEN, 2008).

Certification methods can help distinguish legal from illegal wood and thus create the basis with which to fight illegal logging - one of the main causes of deforestation. Degradation resulting from legal deforestation can also be minimized via credible voluntary certification such as the FSC (Forest Stewardship Council). However the practical checks in place in the field to monitor the flow of legal vs illegal timber are still not tamper-proof. Commonly used are "Chain-of-Custody" methods which seek to assign a paper identification to individual logs that can be tracked along the timber supply chain from logging concession to the mill and product producers. However the problem with such methods is that they are open to falsification along the supply chain, particularly between the logging concession and mill, where most illegally logged timber is introduced into the supply chain (ZAHNEN, 2008).
We present here a test of a DNA identification method for the important Indonesian timber species merbau, to supplement current certification methods. DNA is extracted from logs sampled at the logging concession and a unique genetic fingerprint is generated using 14 microsatellite markers. We test the reliability of DNA extraction and amplification, and confirmatory status of logs resampled at the sawmill.

\section{Methods}

Wood samples were taken from 2627 merbau logs harvested in a logging concession in Papua, Indonesia. These logs were delivered to a sawmill in Java, Indonesia between $14^{\text {th }}$ Nov 2009 and $11^{\text {th }}$ March 2010. Wood samples were taken from a total of $741 \operatorname{logs}$ at the sawmill during this period.

All samples were collected following quality control protocols designed to maintain freshness of wood samples and minimize moisture content. This included the use of zip-lock bags and silica gel desiccants. All individual bags were numbered uniquely and 50 such bags were put in a polyethylene cover and sealed with a tamper proof nylon tag with a unique number. All samples were recorded in a sampling report that also contained data of the sample transfers.

Following guidelines specified in ISO 2859:1999 Special Sampling Plan (developed by Double Helix Tracking Technologies), a selection of 32 samples were randomly chosen from the samples collected at the sawmill and matched with the samples collected from the concession using the signed government transportation documentation.

The sample pairs were then forwarded to the laboratory for DNA analysis. Genomic DNA was extracted from wood samples using the cetyltrimethyl ammonium bromide (CTAB) method and used to amplify 14 microsatellite loci (one chloroplast microsatellite and 13 nuclear

Table 1. - List of polymorphism information content (PIC, from WANG et al., 2009), number of alleles identified across the 32 test samples, approx size of product (bp), and amplification success rate, overall for forest sampled logs and for sawmill sampled logs.

\begin{tabular}{|c|c|c|c|c|c|c|}
\hline Locus & PIC* & $\begin{array}{l}\text { no } \\
\text { alleles }\end{array}$ & $\begin{array}{l}\text { approx } \\
\text { size (bp) }\end{array}$ & $\begin{array}{l}\text { overall } \\
\text { amplificati } \\
\text { on success } \\
(\%)\end{array}$ & $\begin{array}{l}\text { amplificati- } \\
\text { on }(\%) \\
\text { forest } \\
\text { sampled }\end{array}$ & $\begin{array}{l}\text { amplificati- } \\
\text { on (\%) mill } \\
\text { sampled }\end{array}$ \\
\hline A86 & 0.76 & 8 & 236 & 60.9375 & 81.25 & 40.625 \\
\hline $\mathrm{C} 14$ & 0.77 & 7 & 204 & 64.0625 & 81.25 & 46.875 \\
\hline CCMPA & - & 2 & 120 & 64.0625 & 84.375 & 43.75 \\
\hline D20 & 0.84 & 8 & 226 & 43.75 & 50 & 37.5 \\
\hline D56 & 0.43 & 4 & 201 & 65.625 & 71.875 & 59.375 \\
\hline D60 & 0.8 & 9 & 230 & 62.5 & 71.875 & 53.125 \\
\hline D68 & 0.9 & 12 & 194.5 & 53.125 & 56.25 & 50 \\
\hline D88 & 0.48 & 2 & 174 & 15.625 & 15.625 & 15.625 \\
\hline H16 & 0.89 & 13 & 186 & 45.3125 & 50 & 40.625 \\
\hline $\mathrm{H} 22$ & 0.9 & 9 & 259 & 29.6875 & 37.5 & 21.875 \\
\hline I47 & 0.75 & 12 & 318 & 35.9375 & 43.75 & 28.125 \\
\hline I60 & 0.84 & 10 & 173 & 59.375 & 53.125 & 65.625 \\
\hline I70 & 0.73 & 9 & 130.5 & 51.5625 & 62.5 & 40.625 \\
\hline J61 & 0.75 & 9 & 131 & 56.25 & 68.75 & 43.75 \\
\hline
\end{tabular}


Table 2. - For each of the 32 logs sampled, the number of loci that amplified (No. loci), and the probability that another tree from the source population exactly matched that samples genotype using forest samples, sawmill samples and matching combined samples (Prob. match).

\begin{tabular}{|c|c|c|c|c|c|c|c|}
\hline $\log$ & $\begin{array}{l}\text { Fores } \\
\text { No. } \\
\text { loci } \\
\end{array}$ & $\begin{array}{l}\text { sample } \\
\text { Prob. } \\
\text { match } \\
\end{array}$ & $\begin{array}{l}\text { Sawm } \\
\text { No. } \\
\text { loci } \\
\end{array}$ & $\begin{array}{l}\text { iill sample } \\
\text { Prob. } \\
\text { match }\end{array}$ & $\begin{array}{l}\text { Coml } \\
\text { No. } \\
\text { loci }\end{array}$ & $\begin{array}{l}\text { ined } \\
\text { Prob. } \\
\text { match }\end{array}$ & $\begin{array}{l}\text { Verdict, comparison of forest and sawmill } \\
\text { sampled logs }\end{array}$ \\
\hline 1 & 7 & $7.88 \mathrm{E}-08$ & 11 & $1.99 \mathrm{E}-14$ & 6 & $4.93 \mathrm{E}-07$ & Match, very low probability substitution \\
\hline 2 & 4 & $2.16 \mathrm{E}-05$ & 11 & $7.39 \mathrm{E}-15$ & 4 & $2.16 \mathrm{E}-05$ & Match, very low probability substitution \\
\hline 3 & 8 & $2.96 \mathrm{E}-15$ & 11 & $3.42 \mathrm{E}-20$ & 6 & $5.57 \mathrm{E}-12$ & Match, very low probability substitution \\
\hline 4 & 10 & $6.11 \mathrm{E}-13$ & 4 & $1.48 \mathrm{E}-05$ & 4 & $1.48 \mathrm{E}-05$ & Match, very low probability substitution \\
\hline 5 & 8 & $8.75 \mathrm{E}-12$ & 5 & $2.84 \mathrm{E}-08$ & 4 & $2.08 \mathrm{E}-06$ & Match, very low probability substitution \\
\hline 6 & 9 & $1.14 \mathrm{E}-16$ & 4 & 3.22E-09 & 3 & $1.81 \mathrm{E}-07$ & Match, very low probability substitution \\
\hline 7 & 12 & $9.20 \mathrm{E}-18$ & 12 & $9.20 \mathrm{E}-18$ & 12 & $9.20 \mathrm{E}-18$ & Match, very low probability substitution \\
\hline 8 & 12 & $7.07 \mathrm{E}-21$ & 10 & $1.34 \mathrm{E}-17$ & 10 & $1.34 \mathrm{E}-17$ & Match, very low probability substitution \\
\hline 9 & 11 & $2.29 \mathrm{E}-20$ & 0 & - & 0 & - & No amplification in sawmill sample \\
\hline 10 & 6 & $2.24 \mathrm{E}-09$ & 9 & $3.88 \mathrm{E}-13$ & 4 & $7.50 \mathrm{E}-07$ & Match, very low probability substitution \\
\hline 11 & 12 & $9.33 \mathrm{E}-21$ & 13 & $2.84 \mathrm{E}-21$ & 12 & $9.33 \mathrm{E}-21$ & Match, very low probability substitution \\
\hline 12 & 11 & $3.42 \mathrm{E}-16$ & 4 & $1.04 \mathrm{E}-06$ & 4 & $1.04 \mathrm{E}-06$ & Match, very low probability substitution \\
\hline 13 & 12 & $3.83 \mathrm{E}-19$ & 3 & 7.84E-04 & 3 & $7.84 \mathrm{E}-04$ & Match, low probability substitution \\
\hline 14 & 12 & $1.19 \mathrm{E}-20$ & 4 & $2.40 \mathrm{E}-06$ & 3 & $5.99 \mathrm{E}-05$ & Match, very low probability substitution \\
\hline 15 & 2 & $1.54 \mathrm{E}-04$ & 5 & $2.24 \mathrm{E}-08$ & 1 & $7.56 \mathrm{E}-03$ & Match, low probability substitution \\
\hline 16 & 4 & $2.29 \mathrm{E}-05$ & 5 & 2.69E-06 & 1 & $3.27 \mathrm{E}-01$ & Match, moderate probability substitution \\
\hline 17 & 11 & $9.38 \mathrm{E}-16$ & 6 & $5.92 \mathrm{E}-09$ & 4 & $1.94 \mathrm{E}-05$ & Match, very low probability substitution \\
\hline 18 & 10 & $4.14 \mathrm{E}-15$ & 6 & $1.89 \mathrm{E}-09$ & 4 & $4.84 \mathrm{E}-05$ & Match, very low probability substitution \\
\hline 19 & 12 & $3.37 \mathrm{E}-16$ & 10 & $2.85 \mathrm{E}-11$ & 10 & $2.85 \mathrm{E}-11$ & Match, very low probability substitution \\
\hline 20 & 5 & $2.31 \mathrm{E}-04$ & 8 & $1.60 \mathrm{E}-08$ & 5 & $2.31 \mathrm{E}-04$ & Match, low probability substitution \\
\hline 21 & 12 & 5.31E-19 & 6 & 3.92E-12 & 5 & $3.92 \mathrm{E}-10$ & Match, very low probability substitution \\
\hline 22 & 7 & $1.99 \mathrm{E}-11$ & 1 & $3.68 \mathrm{E}-02$ & 1 & $3.68 \mathrm{E}-02$ & Match, low probability substitution \\
\hline 23 & 5 & $2.44 \mathrm{E}-06$ & 11 & $5.01 \mathrm{E}-20$ & 4 & $6.09 \mathrm{E}-05$ & Match, very low probability substitution \\
\hline 24 & 12 & 4.17E-19 & 5 & $5.18 \mathrm{E}-06$ & 4 & $3.32 \mathrm{E}-04$ & Match, low probability substitution \\
\hline 25 & 3 & $3.46 \mathrm{E}-05$ & 2 & - & 0 & - & No amplification in sawmill sample \\
\hline 26 & 2 & $4.78 \mathrm{E}-04$ & 3 & $3.44 \mathrm{E}-04$ & 1 & $1.27 \mathrm{E}-02$ & Match, low probability substitution \\
\hline 27 & 3 & $1.36 \mathrm{E}-05$ & 8 & $3.78 \mathrm{E}-10$ & 1 & $1.07 \mathrm{E}-01$ & Match, moderate probability substitution \\
\hline 28 & 14 & $7.96 \mathrm{E}-23$ & 4 & $1.66 \mathrm{E}-05$ & 4 & $1.66 \mathrm{E}-05$ & Match, very low probability substitution \\
\hline 29 & 8 & $4.34 \mathrm{E}-12$ & 2 & $6.63 \mathrm{E}-04$ & 0 & - & No common loci for forest \& sawmill logs \\
\hline 30 & 7 & $6.32 \mathrm{E}-09$ & 5 & $6.04 \mathrm{E}-07$ & 3 & $1.59 \mathrm{E}-04$ & Match, low probability substitution \\
\hline 31 & 7 & $5.68 \mathrm{E}-09$ & 0 & - & 0 & - & No amplification in sawmill sample \\
\hline 32 & 7 & $9.05 \mathrm{E}-09$ & 0 & - & 0 & - & No amplification in sawmill sample \\
\hline
\end{tabular}

microsatellites) following the protocols of WEISING and GARDNER (1999) and Wong et al. (2009) for chloroplast and nuclear microsatellite loci respectively.

Capillary electrophoresis of the PCR products were carried out using an automated sequencer $\mathrm{ABI}$ Prism ${ }^{\mathrm{TM}}$ 3730 Genetic Analyser (Applied Biosystems), and fragment lengths were determined with the help of internal size standards GeneScan ${ }^{\mathrm{TM}} 600$ LIZ $^{\circledR}$ Size Standard (Applied Biosystems). The software used for determination of the fragment length is GeneMapper 4.0 (Applied Biosystems).

The success of DNA extraction and amplification for each locus was recorded for the 32 logs between logging concession and sawmill samplings and are presented in Table 1 and 2. Across the 32 samples, population allele frequencies were used to calculate the probability of which individual genotypes would occur within the logging concession (LowE et al., 2004; Table 2), as support for the chance of logs of identical genotype being substituted.

\section{Results}

For all 32 samples the amplification success across all 14 loci was $59.2 \%$ for forest concession and $41.9 \%$ for mill samples. The number of alleles at individual loci ranged between 2 and 13 .

Of the 32 samples tested, five either failed to amplify any loci in the sawmill sample (4) or amplified different loci in forest and sawmill samples (1). Of the 27 samples for which a common set of loci amplified in both forest and sawmill samples, all produced an exact genotype match between the samples. However the number of common loci amplified varied between 1 and 12 and some loci only exhibited 2 alleles. Therefore for each log, the probability of an identical genotype being present within the forest concession was calculated based on the loci which amplified in both forest and sawmill samples, and provides a test of the likelihood that an illegally substituted log would have the same genotype as the forest sampled log. Based up on these probabilities, logs 


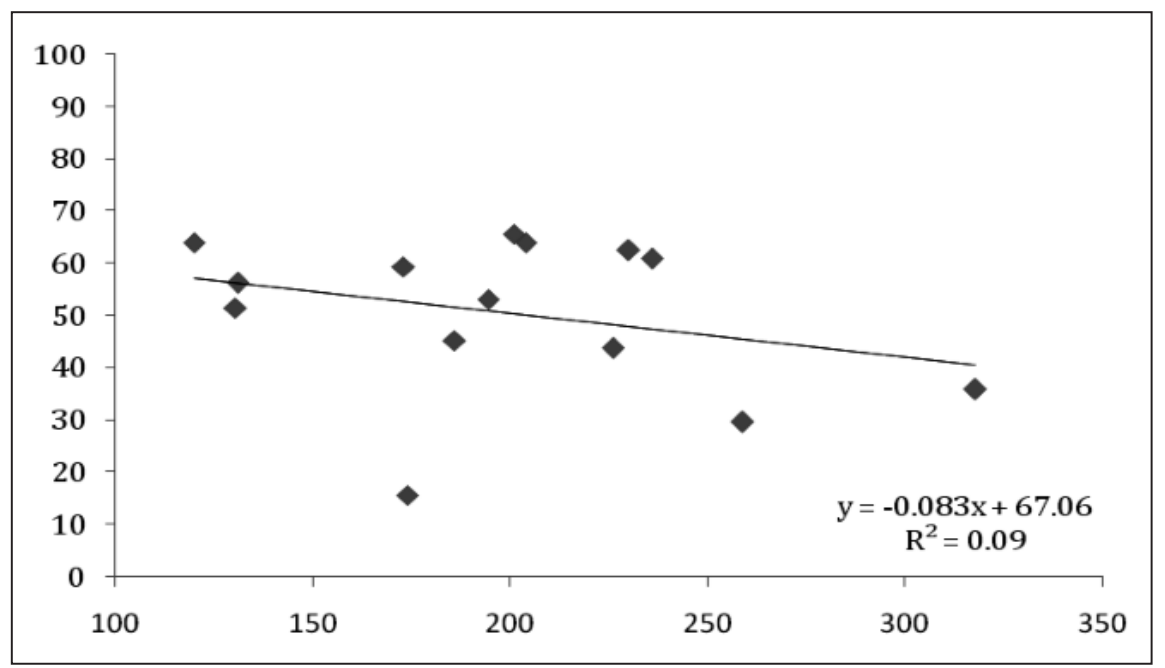

Figure 1a. - Overall amplification success (\%) by size of microsatellite loci (bp).

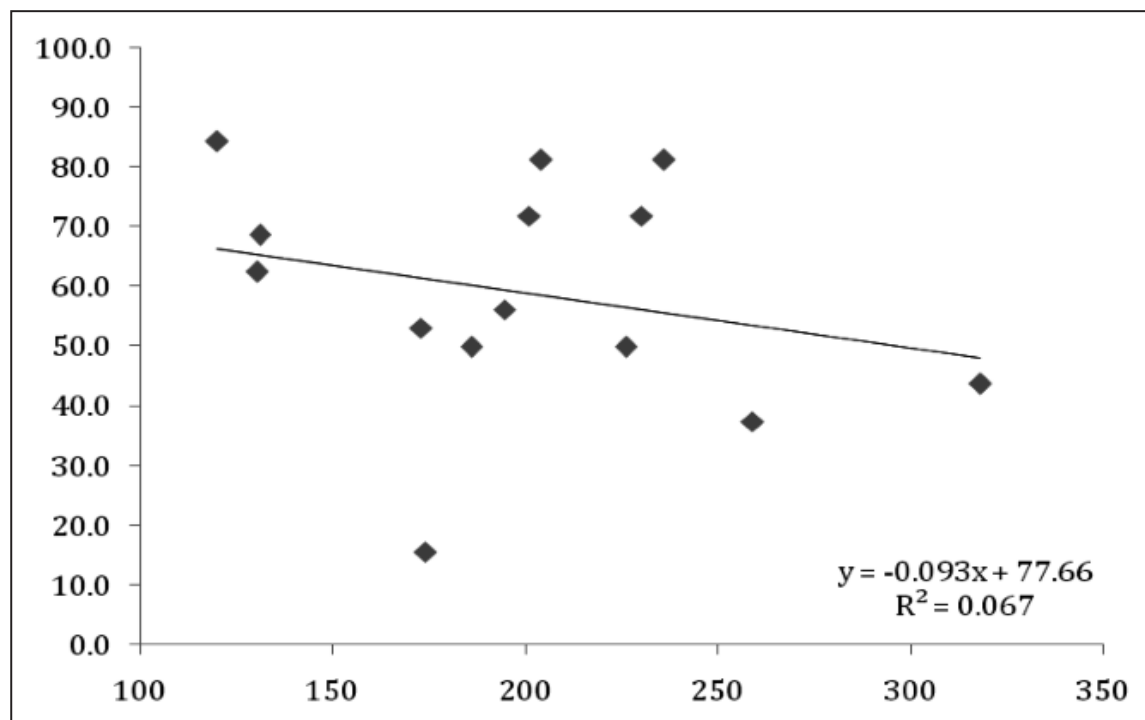

Figure 1b. - Amplification success (\%) of forest sampled logs by size of microsatellite loci (bp).

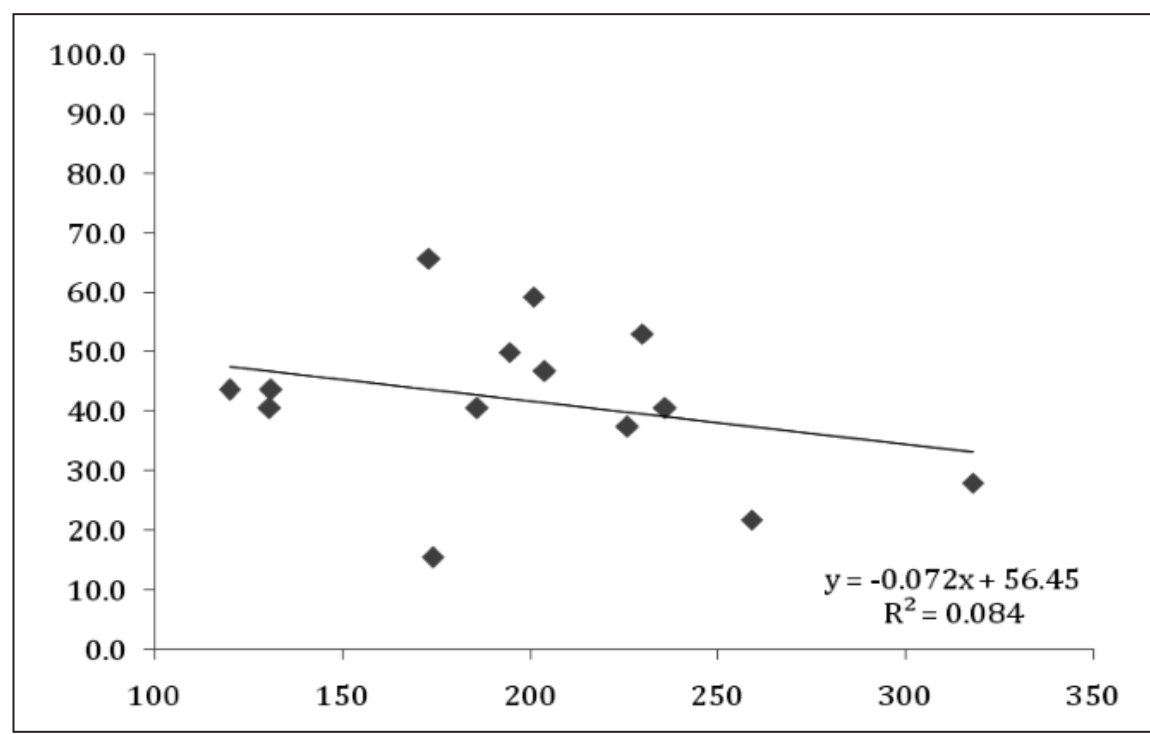

Figure 1c. - Amplification success (\%) of sawmill sampled logs by size of microsatellite loci (bp). 


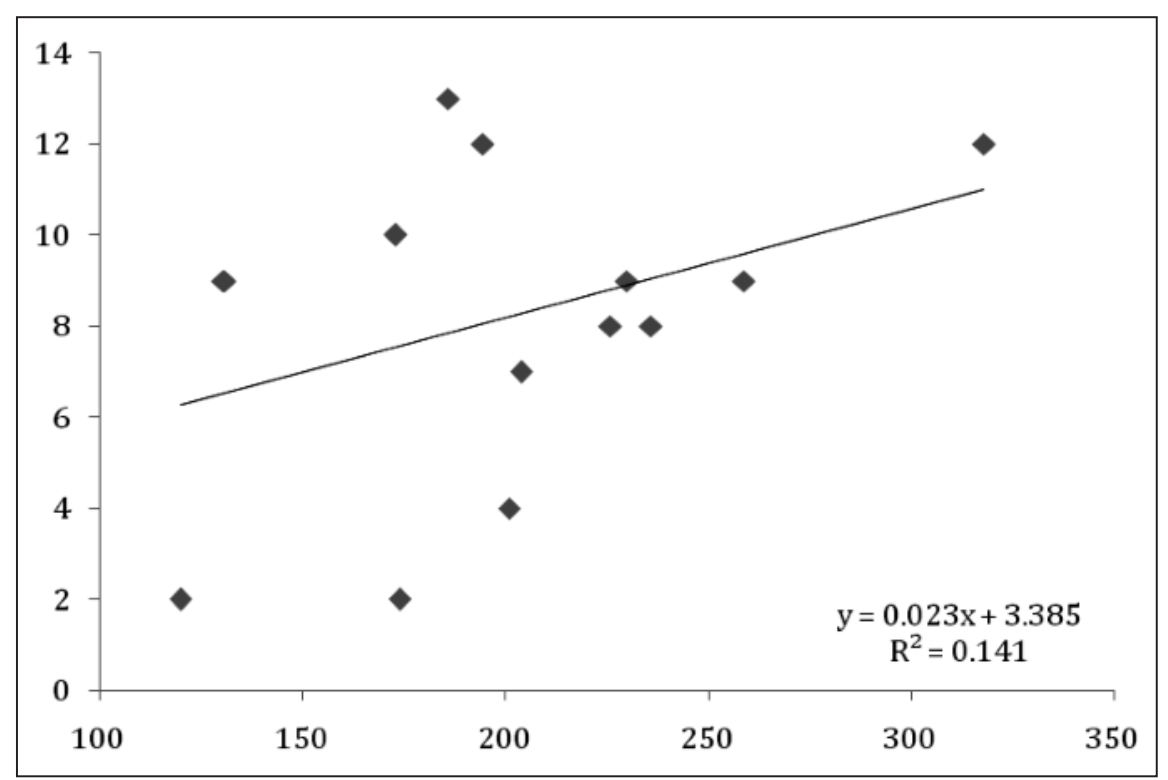

Figure 1d. - Number of alleles identified at each locus by microsatellite locus size.

were classified into: very low probability of an identical genotype within the population $\left(10^{-5}\right.$ to $10^{-18}$, i.e. a 1 in $100,000^{\text {th }}$ chance or lower, 18 samples); low probability of an identical genotype within the population $\left(10^{-2}\right.$ to $10^{-4}$, i.e. 1 in 100 to 1 in 10,000 chance, 7 samples); moderate probability ( 1 in 10 chance, 2 samples); Table 2.

Amplification success decreased with amplicon size across all samples and for forest and sawmill sampled logs separately (Figs. 1a-c). Number of alleles also demonstrated a positive correlation with amplicon size (Fig. 1d).

\section{Discussion}

This paper describes the development of a methodology to track a unique genetic fingerprint for single logs of merbau, a high-value Indonesian timber species, from logging concession to the mill. It is this stage in the supply chain which is most prone to the substitution of illegally harvested timber and the development of a DNAbased method which will be very difficult/impossible to tamper with will be a significant improvement over/complementation to paper based methods to trace logs back to a legal or sustainable source (DEGEN and FLADUNG, 2008; ZAHNEN, 2008).

We find that whilst the ability to extract DNA and amplify a PCR product from logs decreases slightly between forest concession $(59.2 \%)$ and sawmill (41.9\%) samples, that overall enough samples worked across the 14 microsatellite markers to provide an exact genotype match between forest and sawmill samples for 27 out of 32 logs. Of the five samples where this test was not possible for four the sawmill sample failed to amplify and for one, non-overlapping loci were amplified between forest and sawmill samples.

Overall there was a negative correlation between amplicon size and amplification success (across all samples and in forest and sawmill samples separately), but a positive correlation with allele number. Thus whilst polymorphism increases with locus size, the probability of amplification decreases. Generally loci with a size of $200 \mathrm{bp}$ still amplified with reasonable success but were also polymorphic. Further developments to reduce the locus size of the larger loci and development of additional markers would be useful. In addition developments in the extraction of DNA from timber sources (e.g. DEGUILLOUX et al., 2002; DumOLIN-LAPĖGUe et al., 1999; SPEIRS et al., 2009) are likely to bring increased amplification success.

Of the 27 samples for which the forest and sawmill genotypes matched, it was possible to calculate a probability that a particular genotype occurred within the logging concession population. This calculation is based upon allele frequencies across all samples and is calculated individually for the loci in common between forest and sawmill samples, and provides a test of the probability that an illegal log substituted along the supply chain has the same genotype as forest samples. Thus the probability of a matching genotype was very low (less than $10^{-5}$ ) for 18 samples, was low (between $10^{-2}$ and $10^{-4}$ ) for 7 samples and was moderate $\left(10^{-1}\right)$ for 2 samples.

Overall we propose that this DNA tracking methodology is now suitable for broad-scale industry application to track legally harvested timber and check for illegal substitutions along supply chains, and complements paper certification methods and DNA source identification methods based on genetic structure (e.g. DEGUILLOUX et al., 2003; Lowe et al., 2004; Lowe, 2008; LEMES et al., 2010).

\section{Acknowledgements}

We are grateful to the International Tropical Timber Organization (ITTO) for funding this work, to the Double Helix field team for collecting samples, to the National University of Singapore for supporting lab work and the University of Adelaide for supporting data analysis. 


\section{References}

Degen, B. and M. Fladung (2008): Use of DNA-markers for tracing illegal logging. In: Proceedings of the international workshop "Fingerprinting methods for the identification of timber origins" October 8-9 2007, Bonn/Germany (Ed. BERND DEGEN). Landbauforschung, vTI Agriculture and Forestry Research, Sonderheft 321, Germany. Pp 6-14.

Deguilloux, M. F., M. H. Pemonge, L. Bertel, A. Kremer and R. J. Pетіт (2003): Checking the geographical origin of oak wood: molecular and statistical tools. Mol Ecol 12: 1629-1636.

Degullloux, M. F., M. H. Pemonge and R. J. Petit (2002): Novel perspectives in wood certification and forensics: dry wood as a source of DNA. Proc R Soc Lond B: Biological Sciences 269: 1039-1046.

Lemes, M. R., C. W. Dick, C. Navarro, A. J. Lowe, S. CAVERS and R. GRIBEL (2010): Chloroplast DNA microsatellites reveal contrasting phylogeographic structure in mahogany (Swietenia macrophylla King, Meliaceae) from Amazonia and Central America. Tropical Plant Biology 3: 40-49.

Dumolin-Lapègue, S., R. J. Petit, L. Gielly and P. TaberLET (1999): Amplification of DNA from ancient and modern oak wood. Mol Ecol 8: 2137-2140.

Lowe, A. J. (2008): Can we use DNA to identify the geographic origin of tropical timber? In: Proceedings of the international workshop "Fingerprinting methods for the identification of timber origins" October 8-9 2007, Bonn/Germany (Ed. BERND DEGEN). Landbauforschung, vTI Agriculture and Forestry Research, Sonderheft 321, Germany. Pp 15-19.
Lowe, A. J., S. A. HARRIS and P. AshTON (2004): Ecological Genetics: Design, Analysis and Application. Blackwells, Oxford. $326 \mathrm{pp}$.

Lowe, A., R. C. Munro, S. Samuel, and J. Cottrell (2004): The utility and drawbacks of chloroplast DNA for identifying native British oak stands. Forestry. 77: 335-347.

Speirs, A., G. McConnachie and A. J. Lowe (2009): Chloroplast DNA from $16^{\text {th }}$ century waterlogged oak in a marine environment: initial steps in sourcing the Mary Rose timbers. In: Archaeological Science Under a Microscope: Studies in Residue and DNA Analysis in Honour of Tom Loy (Eds. HASLAM, ROBERTSON, Crowther, Kirkwood and Nugent). Chapter 13 pp 165-179. Terra Australis

WEISING, K. and R. C. GARDNER (1999): A set of conserved PCR primers for the analysis of simple sequence repeat poly-morphisms in chloroplast genomes of dicotyledonous angiosperms. Genome 42, 9-19.

Wong, K. N., W. L. TAN and F. T. CHEW (2009): Identification and characterization of microsatellite loci in Intsia palembanica (Leguminosae), a valuable tropical timber species. Molecular Ecology Resources 9, 360-364.

ZAHNEN, J. (2008): Foreword from WWF-Germany. In: Proceedings of the international workshop "Fingerprinting methods for the identification of timber origins" October 8-9 2007, Bonn/Germany (Ed. BERND DEGEN). Landbauforschung, vTI Agriculture and Forestry Research, Sonderheft 321, Germany. Pp 5.

\title{
Use of DNA-Fingerprints to Control the Origin of Forest Reproductive Material
}

\author{
By B. Degen ${ }^{1), *)}$, A. Höltken ${ }^{2)}$ and M. RoGGe ${ }^{3)}$
}

(Received 28 $8^{\text {th }}$ May 2010)

\begin{abstract}
Well-adapted, high quality reproductive material is key to the success of forest plantations. Consequently in many countries the collection and trade of forest reproductive material is regulated. Paper documents are usu-

\footnotetext{
1) Johann Heinrich von Thünen Institut, Institut für Forst genetik, Sieker Landstrasse 2, D-22927, Grosshansdorf, Germany.

2) Plant Genetic Diagnostics GmbH, Sieker Landstrasse 2, D-22927, Grosshansdorf, Germany. E-Mail: hoeltken@holz.unihamburg.de

3) Landesbetrieb Wald und Holz Nordrhein-Westfalen, Obereimer 13, D-59821 Arnsberg, Germany. E-Mail: martin.rogge@waldund-holz.nrw.de

*) Corresponding author: BERND DEGEN. Johann-Heinrich-vonThünen-Institut, Institut für Forstgenetik, Sieker Landstrasse 2, D-22927, Grosshansdorf, Germany. E-Mail: bernd.degen@ vti.bund.de
}

ally the only evidence for the origin of forest reproductive material. Certification schemes already established in Germany use genetic inventories to compare reference samples collected at different steps of the chain-ofcustody. A new approach using DNA-fingerprints efficiently controls the origin of seed sources without these multiple reference samples. Only a sample of adult trees within the seed stands is needed. The control is directly made for each suspicious plant or a group of suspicious plants by use of multilocus genotype assignment. We made a field test with samples of adults and seedling from 5 registered seed stands of Quercus robur in Western Germany. Eight highly variable nuclear microsatellites were used to genotype each individual. We found in total 255 different alleles at all loci in the adult populations. The observed levels of genetic variation $\left(A_{e}=9.18\right)$, genetic differentiation (delta $=0.187$ ) and population fixation $\left(\mathrm{F}_{\mathrm{ST}}=0.01\right)$ were slightly higher than results 